$\mathrm{A} \mathrm{J}_{\mathrm{atas}} \mathrm{H}$

Article history :

Received : 06.12.2015

Revised : 10.04.2016

Accepted : 22.04.2016

Author for correspondence

MANOJ KUMAR SINGH

Krishi Vigyan Kendra, Pampoli,

EAST KAMENG (ARUNACHAL

PRADESH) INDIA

Email : mr.mksingh2008@ rediffmail. coM
THEASIAN JOURNALOF HORTICULTURE

Volume 11 | Issue 1 | June, 2016 | 44-46

Visit us -www.researchjournal.co.in
RESEARCH PAPER

DOI : 10.15740/HAS/TAJH/11.1/44-46

\title{
Genetic analysis of yield and its contributing traits in brinjal (Solanum melongena L.)
}

\section{MANOJ KUMAR SINGH}

ABSTRACT : Analysis of variance showed highly significant differences for all the characters among the treatments. The orthogonal partitioning of treatment of parents, $\mathrm{F}_{1} \mathrm{~s}, \mathrm{~F}_{2} \mathrm{~s}$, parents $v s$ $\mathrm{F}_{1} \mathrm{~s}$, parents $v s \mathrm{~F}_{2} \mathrm{~s}$ and $\mathrm{F}_{1} \mathrm{~s} v s \mathrm{~F}_{2} \mathrm{~s}$ were also highly significant for all the characters except for parents $v s \mathrm{~F}_{2} \mathrm{~s}$ (Number of branches per plant) and significant for parents $v s \mathrm{~F}_{2} \mathrm{~s}$ (fruit yield per plant).Wide range of variability was observed for all the characters for parents, $\mathrm{F}_{1} \mathrm{~s}$ and $\mathrm{F}_{2} \mathrm{~s}$ population. The analysis of variance showed highly significant differences among genotypes for all the ten characters, viz., days to flowering, height of plant, number of branches per plant, length of leaf, width of leaf, length of fruit, width of fruit, number of fruit per plant, weight of per fruit and fruit yield per plant, indicating sufficient variability for undertaking the present investigation.

KEY WORDS : Analysis of variance, (ANOVA), Analysis of the variance for combining ability

HOW TO CITE THIS ARTICLE : Singh, Manoj Kumar (2016). Genetic analysis of yield and its contributing traits in brinjal (Solanum melongena L.). Asian J. Hort., 11(1) : 44-46, DOI : 10.15740/ HAS/TAJH/11.1/44-46. 